\title{
Auditory brainstem response prior to MRI compared to standalone MRI in the detection of vestibular schwannoma: a modelling study
}

\author{
Stan Wijn ${ }^{1}$, Mayke Hentschel ${ }^{1}$, Andy Beynon ${ }^{1}$, Henricus Kunst ${ }^{1}$, and Maroeska Rovers ${ }^{1}$ \\ ${ }^{1}$ Radboudumc
}

July 17, 2021

\begin{abstract}
Objectives: To determine the cost-effectiveness of auditory brainstem response prior to MRI (ABR-MRI) compared to standalone MRI to diagnose vestibular schwannoma. Design: A state transition decision-analytic model was developed to simulate costs and effects (quality-adjusted life years) for both treatment strategies for patients suspected of a vestibular schwannoma. Model input was derived from literature, hospital databases, and expert opinions. Scenario and sensitivity analyses addressed model uncertainty. Results: Over a lifetime horizon, ABR-MRI resulted in a limited cost-saving of \euro68 or \euro98 per patient (dependent on MRI sequence) and a health loss of 0.005 QALYs over standalone MRI. ABR-MRI, however, did miss patients with other important pathology ( $2 \%$ of the population) that would have been detected when using standalone MRI. Calculating the incremental cost-effectiveness ratio resulted in \euro14,203 or \euro19,550 saved per lost QALY if ABR-MRI was used instead of standalone MRI. The results were sensitive to the detection rate of vestibular schwannoma and healthrelated quality of life of missed patients. Conclusion: The cost-saving with ABR-MRI does not seem to outweigh the number of missed patients with VS and other important pathologies that would have been detected when using standalone MRI.
\end{abstract}

\section{Hosted file}

ABR-MRI article v2.6_Manuscript.docx available at https://authorea.com/users/426173/articles/ 530778-auditory-brainstem-response-prior-to-mri-compared-to-standalone-mri-in-thedetection-of-vestibular-schwannoma-a-modelling-study 

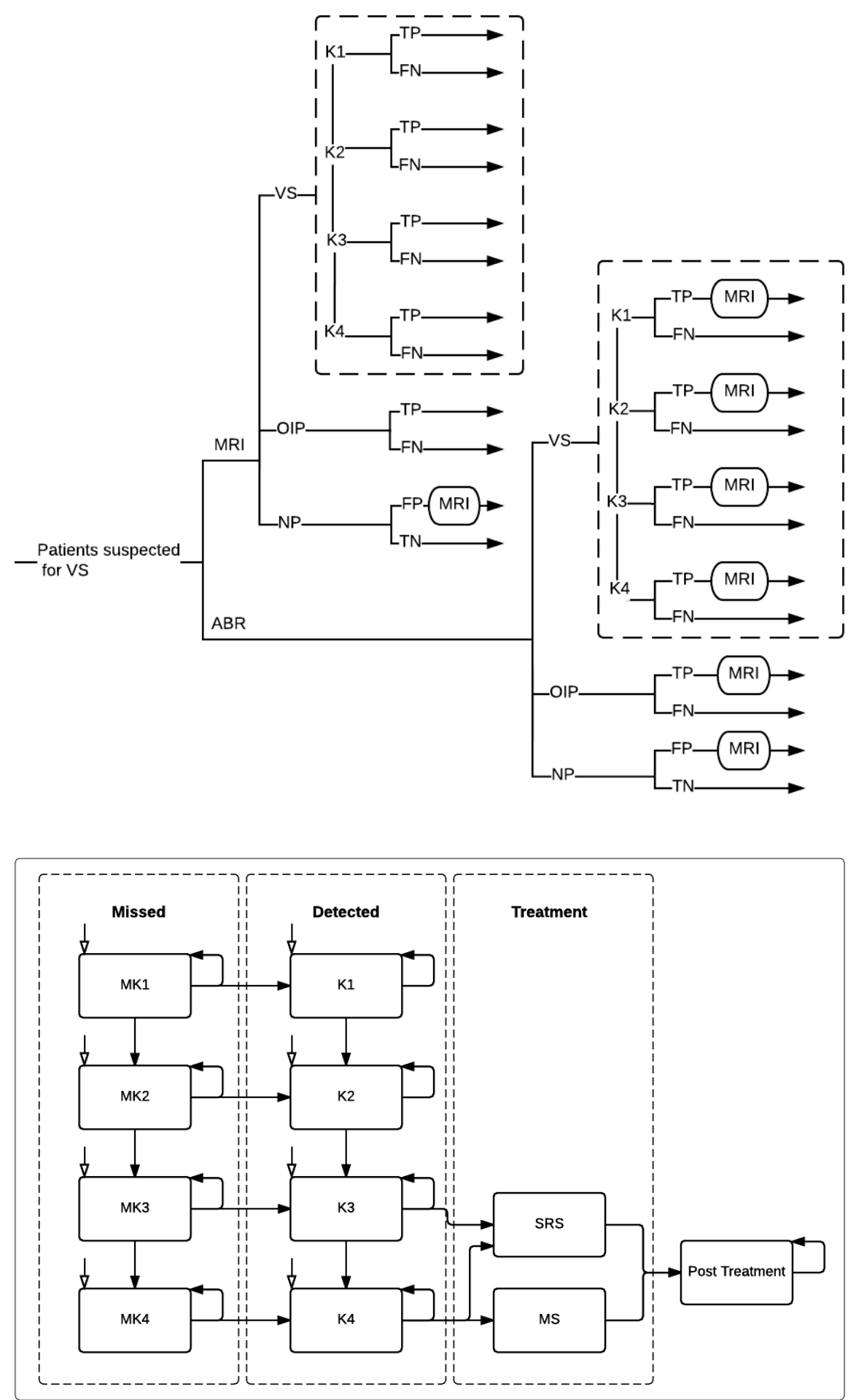


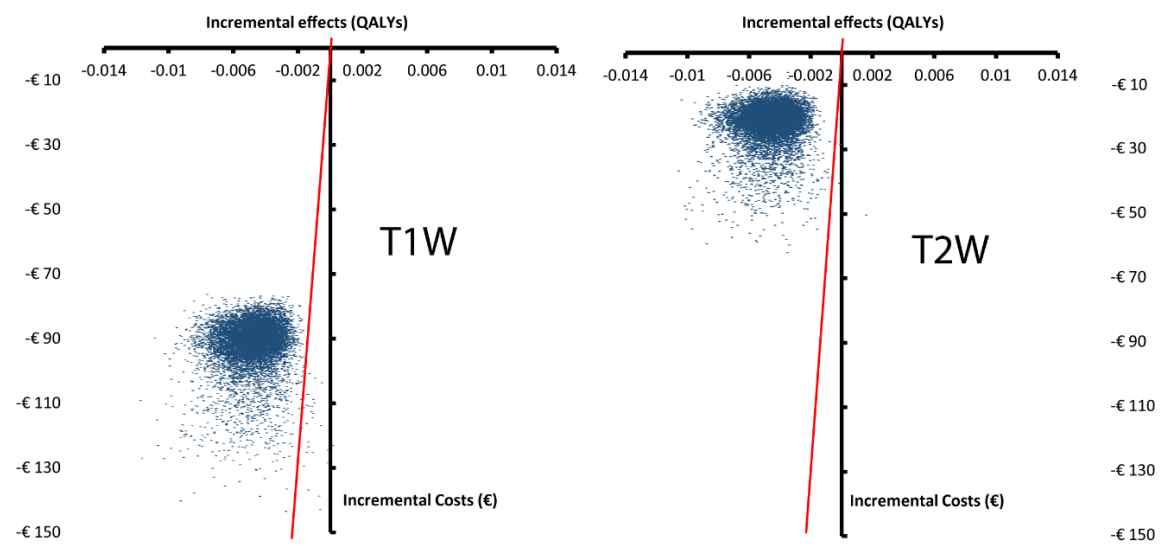

\section{Hosted file}

Table 1.docx available at https://authorea.com/users/426173/articles/530778-auditorybrainstem-response-prior-to-mri-compared-to-standalone-mri-in-the-detection-ofvestibular-schwannoma-a-modelling-study

\section{Hosted file}

Table 2.docx available at https://authorea.com/users/426173/articles/530778-auditorybrainstem-response-prior-to-mri-compared-to-standalone-mri-in-the-detection-ofvestibular-schwannoma-a-modelling-study

\section{Hosted file}

Table 3.docx available at https://authorea.com/users/426173/articles/530778-auditorybrainstem-response-prior-to-mri-compared-to-standalone-mri-in-the-detection-ofvestibular-schwannoma-a-modelling-study 